\title{
Effect of Mechanical Vibrations During Transport Operations of Nilo Tilapia (Oreochromis niloticus)
}

\author{
P. M. Rebouças ${ }^{1}$, J. S. Almeida ${ }^{2}$, W. I. S. Paula ${ }^{3}$, R. S. Rocha ${ }^{4}$, S. A. A. Almeida ${ }^{5}$, J. A. D. Barbosa-Filho ${ }^{1}$ \\ \& P. P. Rebouças-Filho \\ ${ }^{1}$ Department of Agricultural Engineering, Federal University of Ceara, Ceará, Brazil \\ ${ }^{2}$ Computer Science Center, Federal Institute of Education, Science and Technology of Ceará, Ceará, Brazil \\ ${ }^{3}$ School of Social Communication, University Center September 7, Ceará, Brazil \\ ${ }^{4}$ Institute of Marine Sciences, Federal University of Ceara, Ceará, Brazil \\ ${ }^{5}$ School of Aquaculture Engineering, Federal Institute of Education, Science and Technology of Ceará, Ceará, \\ Brazil \\ Correspondence: P. M. Rebouças, Center for Agricultural Sciences, Department of Agricultural Engineering, \\ Federal University of Ceará, Mister Hull Avenue, 3610, Ceará, Brazil. Tel: 55-85-996-884-608. E-mail: \\ perilamaciel@yahoo.com.br
}

$\begin{array}{lc}\text { Received: June 12, } 2019 & \text { Accepted: August 11, } 2019 \quad \text { Online Published: October 15, } 2019 \\ \text { doi:10.5539/jas.v11n17p295 } & \text { URL: https://doi.org/10.5539/jas.v11n17p295 }\end{array}$

The research is financed by IFCE, UFC and CAPES.

\begin{abstract}
Oscillatory movements present in the transport of live fish may compromise the physiological stability and the future performance of the animals. Therefore, the objective of this research was to evaluate the effect of mechanical vibrations in the transport of Nile tilapia through vibration levels and shocks occurred in transport boxes previously installed in a truck. The research was carried out in a fish farming integrating company in the state of Ceará, Brazil, with the monitoring of 5 live fish loads. The transport truck used was of the open type, with capacity for five boxes of fiberglass with a useful volume of $2400 \mathrm{~L}$, density of $236 \mathrm{~kg} \mathrm{~m}^{-3}$. The data were recorded through five dataloggers, to monitor the vibration level $\left(\mathrm{m} \mathrm{s}^{-2}\right)$ and the occurrence and amplitude of mechanical shocks on the roads. Hematological, metabolic and ionic responses of fish were evaluated as well as visual observations of physical injuries. The most intense shocks occurred with the truck between 60 and $80 \mathrm{~km}$ $\mathrm{h}^{-1}$, with vibrations $1.151 \mathrm{~m} \mathrm{~s}^{-2}$ in the transport box, as well as in the water $0.489 \mathrm{~m} \mathrm{~s}^{-2}$. Larger vibration levels occurred on the asphalt road, with an average value of $1.13 \mathrm{~m} \mathrm{~s}^{-2}$, while on the dirt road they registered an average of $0.57 \mathrm{~m} \mathrm{~s}^{-2}$. Vibratory and mechanical stimuli presented secondary responses to blood level stress with alterations in glycemia, hematocrit, hemoglobin and magnesium ions. Physical lesions with $34 \%$ severe and $21 \%$ moderate, showed an uncomfortable environmental condition to fish.
\end{abstract}

Keywords: ambience, fish farming, well-being

\section{Introduction}

The world production of animal protein has been steadily increasing, as well as consumer demands for products that meet their needs and desires (FAO, 2018). One of the main sources of protein in the world is supplied by aquaculture. Fish handling procedures in aquaculture, such as capture, handling and transport, are often traumatic and may cause serious physiological and biochemical reactions. The direct effects of stress are those that influence the organism of the fish, altering physiological functions, hormones or cellular mechanisms. However, the indirect effects act at the population level, affecting the trophic relationships in the productive environment (Alves et al., 2016; Goes et al., 2018).

The stress response corresponds to a series of physiological changes. The effects are divided into primary, secondary and tertiary, characterized by increases in catecholamines, adrenaline and noradrenaline, and corticosteroids in plasma, changes in blood glucose, lactic acid, hepatic and muscle glycogen, the declines in productive and reproductive performance and resistance to diseases, respectively (Navarro et al., 2017). Thus, 
stress can affect the quality of fish meat. Therefore, animals stressed before slaughter enter rigor mortis more quickly, reducing the useful life of the fish (Mendes et al., 2015).

Hematology is a tool used to aid diagnosis and prognosis of fish to different environmental challenges. The knowledge of hematological reference values for each species of fish is of great relevance, since environmental and physiological variations interfere in the homeostatic pattern of these animals. Thus, the blood parameters can be used as biological indicators for monitoring fish health, being used as a tool for the diagnosis of animal stress imbalance influenced by the environment or due to the presence of infectious agents (Silva, Rocha, Fortes, Vieira, \& Fioravanti, 2012).

According to Nazareno et al. (2015) road quality can have serious impacts on the load to be considered in transport planning, noting that the worst levels of vibration and shocks occur vertically as a result of overshoots and sudden braking as well as on asphalt roads in function of the vehicle. For Miranda de la Lama et al. (2014), most of the vehicles are not designed to reduce vibrations experienced by animals knowing that vibration levels are influenced by the type of suspension, engine speed, number of axles and tire calibration (Nazareno et al., 2013).

Gebresenbet et al. (2011) reported that exposure to the effects of vibrations during transport caused discomfort to the animals moving from their center of balance, causing them to injure themselves (Nazareno et al., 2015), or by the physical and agonistic behavioral interaction with other animals or through concussion with the tank walls (Turnbull \& Kadri, 2007).

There is still no research on the influence of vibration levels produced during live fish transport practices, nor on a limit of comfort and wellbeing, unlike other species of animals such as horses (Niedźwiedź, Kubiak, \& Nicpón, 2013), and pigs (Smith et al., 2004) and cattle (Mendonça et al., 2016; Schwartzkopf-Genswein, Faucitano, Dadgar, Shand, \& González, 2012), which already have a standard considered adequate. Thus, it is of fundamental importance to understand the benefits to be achieved with the introduction of programs aimed at minimizing the effect of stress on animal welfare and on the final products generated from this exploitation, especially for Nile tilapia, a precursor aquatic species of this study. In view of the above, this work has the objective of evaluating the effect of mechanical vibrations during Nile tilapia transport operations.

\section{Method}

\subsection{Location and Experimental Conditions}

The research was conducted by a fish company located in the State of Ceará, Brazil, presenting latitude of $5^{\circ} 6^{\prime} 20^{\prime \prime}$ South and longitude: $38^{\circ} 22^{\prime} 2^{\prime \prime}$ West. The experimental periods were from September to October of 2018 and March of 2019, accompanying 5 shipments of live fish from the municipality of Morada Nova/CE to the municipality of Fortaleza/CE, Brazil. During the experimental period were quantified, per second, the vibration levels, mechanical shocks, force g, path, average speed of the truck and water temperature through attached dataloggers in a fiberglass box with useful volume of 2400 L. Four of these dataloggers (Figure 1) were attached at the upper ends of the last transport carton (front right, front left, right rear and left rear), measuring range $\pm 3 \mathrm{~g}$ or $29.4 \mathrm{~m} \mathrm{~s}^{-2}$. The recording intervals were 1 second at the constant $27 \mathrm{~Hz}$ frequency.

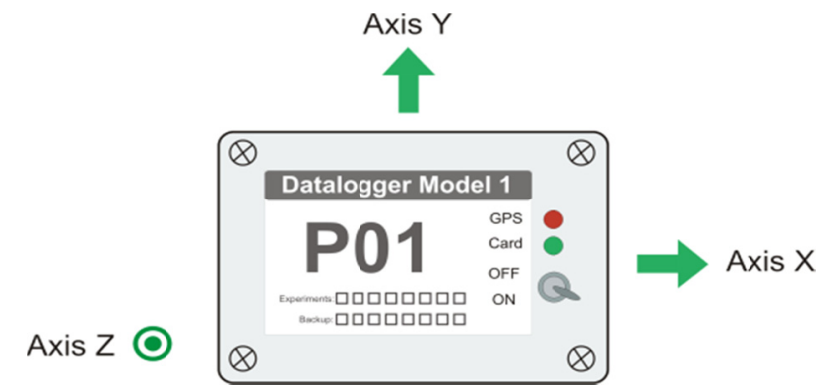

Figure 1. Illustration of the datalogger and description of the axes of the accelerometer; during installation the same orientation was always followed during attachment to the tanks

During the five shipments accompanied, a single driver carried the transport. In all transports, the datalloggers were installed in a fiberglass transport box with a $2400 \mathrm{~L}$ useful volume, density of $236 \mathrm{~kg} \mathrm{~m}^{-3}$, BERAQUA model E-22400, $2.26 \mathrm{~m}$ long, $1.15 \mathrm{~m}$ width and 1.05 $\mathrm{m}$ in height (Figure 2). The transport truck was of the open 
type, model 9-150 E of Volkswagen, presenting the following dimensions: $7.5 \mathrm{~m}$ in length, 2.6 in width and 2.6 in height, with three axles. Tire calibration was done at 100 pounds, and the suspension type was with parabolic springs and double acting hydraulic shock absorbers.

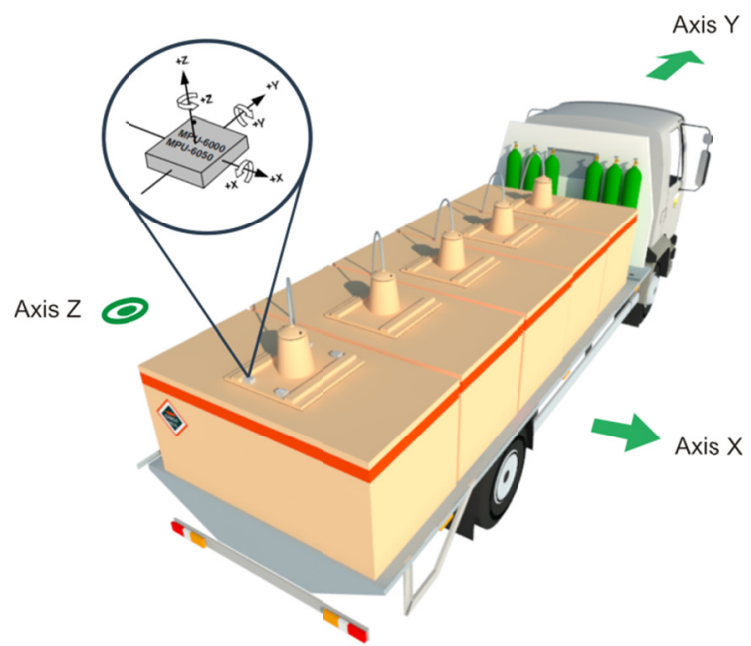

Figure 2. Description of the accelerometer, gyroscope and orientation sensor axes adopted in this research in relation to the truck in the $\mathrm{X}, \mathrm{Y}$ and $\mathrm{Z}$ direction, respectively, $\mathrm{X}$ lateral direction (left side to the right), $\mathrm{Y}$ horizontal direction (front to back ) and $\mathrm{Z}$ vertical direction (from floor to top); the dataloggers were attached to the lid of the last tank

\subsection{Procedures and Variables Analyzed}

Twenty-eight fish were monitored throughout the survey. The organisms were packed in a shipping carton, 236 $\mathrm{kg} \mathrm{m}^{-3}$, each fish having an average individual weight $\pm 1200 \mathrm{~g}$. All fish were maintained for a minimum of 24 hours fasting, and then anesthetized with Eugenol® solution at a concentration of $50 \mathrm{mg} \mathrm{L}^{-1}$, according to Vidal Oliveira et al. (2008). The evaluated fish were individually tagged with external, sequentially numbered, yellow-colored tags, by insertion in the anterior portion of the insertion musculature of the 6th dorsal fin, according to methodology described by Teixeira (2007). After the desensitisation, $0.5 \mathrm{~mL}$ of $\mathrm{blood}_{\text {fish }}{ }^{-1}$ were collected by puncturing the caudal vessels, using $3 \mathrm{~mL}$ syringes, immersed in 3\% EDTA anticoagulant, with $26 \times$ $7 \mathrm{~mm}$ needles. Blood glucose concentrations were measured using a Contour TS BAYER® digital meter. The chloride and magnesium ions were analyzed by the LABTEST ${ }^{\circledR}$ kit. The collected blood was inserted into a 250 EDTAk2 ${ }^{\circledR}$ tube, $250-500 \mu \mathrm{l}$, for laboratory hematology analysis: plasma total protein $\left(\mathrm{g} \mathrm{dL}^{-1}\right)$, erythrocyte count $\left(10^{6} \mathrm{~mm}^{-3}\right)$; mean corpuscular volume (VCM) (fL); mean corpuscular hemoglobin (HCM) ( $\left.\mu \mathrm{g}\right)$; mean corpuscular hemoglobin concentration $(\mathrm{CHCM})\left(\mathrm{g} \mathrm{dL}^{-1}\right)$; total hemoglobin $\left(\mathrm{g} \mathrm{dL}^{-1}\right)$ and hematocrit $(\%)$.

The number of erythrocytes was counted using the hemocytometer method, in a Neubauer chamber, with toluidine blue (Merck Chemical, Brooklin Novo, SP), $0.01 \%$, diluted in $0.9 \%$ physiological solution with a pipette of Thoma, in the proportion of 1:200. The hemoglobin ( $\mathrm{Hb})$ was determined by the cyanometahemoglobin method, with the commercial kit Analisa Diagnóstica (Gold Analisa Diagnostica Ltda, Belo Horizonte, MG), for colorimetric determination, according to Collier (1944). The percentage of hematocrit (Hct) was determined by the microhematocrit method, according to Goldenfarb et al. (1971). Total plasma protein (PPT) was measured by the Goldberg manual refractometer, with a microhematocrit tube rupture, after reading the hematocrit (Jain, 1986). Subsequently, hematimetric indices were calculated, according to Wintrobe (1934), as described below: Mean corpuscular volume [VCM $=(\mathrm{Htc} \times 10)$ /erythrocytes]; Mean Corpuscular Hemoglobin Concentration $[\mathrm{CHCM}=(\mathrm{Hb} / \mathrm{Hct}) \times 100]$. Before and after transportation, samples were also collected and the physical and chemical parameters of the water in the transport box were determined. The parameters of water quality were measured: $\mathrm{pH}$, temperature $\left({ }^{\circ} \mathrm{C}\right)$ and dissolved oxygen $\left(\mathrm{mg} \mathrm{L}^{-1}\right)$ through, respectively, a digital pH meter, AKROM mark and a digital oximeter, brand MO900. Samples of non-ionizable ammonia (toxic to animals) were sent for further analysis in triplicate in the laboratory.

The frequency and severity level of the physical lesions of Nile tilapia before and after transportation were evaluated. However, no lesions were identified prior to submission to the challenge of mechanical shocks and 
vibratory stimuli. Agonistic physical lesions were recorded on the basis of the Nile tilapia evagram prepared by Alvarenga and Volpato (1995) and Mueller et al. (2017). The severity of the lesions was distinguished in four categories: no lesions, low lesion (lesion in the caudal, dorsal, ventral and pectoral fin), moderate lesion (jumping eyes, abnormal color eyes and loose scales) and severe injury and with visible parasites). To register the severity of the different lesions, the fish body was subdivided into distinct anatomical sections: caudal, dorsal, ventral and pectoral fins (left and right sides respectively), including the eyes and identification of parasites throughout the fish body. Fungal and parasitic infections were evaluated first, followed by the presence and intensity of different types of lesions in different parts of the body. The intensity of the trauma was visually estimated by one person, while a second person recorded all the information in the protocol. In this study, the visual estimation of lesions in the field following the proposed protocol took an average of 2 minutes per fish to evaluate all parts of the body and types of lesions. To evaluate injuries in fish were placed individually alive and not euthanized in a transparent plastic box, $40 \mathrm{~L}$, with water from the Curral Velho reservoir, Morada Nova municipality, Ceará, Brazil. All the technical investigators were trained or trained previously by a detailed training exercise on the use of the protocol, using the score sheet (Table 1).

Table 1. Description of injury types and general health criteria

\begin{tabular}{ll}
\hline Description & \\
\hline Types of physical injuries & \\
\hline $\begin{array}{l}\text { Wounds in the caudal, dorsal, } \\
\text { ventral and pectoral fin }\end{array}$ & $\begin{array}{l}\text { Skin lesion between fine rays. Wounds can range from small cuts between fine rays and fully } \\
\text { cracked fins. } \\
\text { Skipped eyes }\end{array}$ \\
$\begin{array}{l}\text { Eyes with abnormal coloring } \\
\text { Change in normal pigmentation of the eyes, usually visible, such as partial or total opacity of the } \\
\text { lens or dark coloration. }\end{array}$ \\
$\begin{array}{l}\text { Lesions in the eyes reaching from small abrasions to deeper wounds with lesion of the eye tissue. } \\
\text { Injured eyes }\end{array}$ \\
$\begin{array}{l}\text { Any part of the body with loose scales. } \\
\text { Parasites visible externally (e.g., lichens, cilia, arthropods) or other visible indicators of parasites } \\
\text { (e.g., white or black spots) on the skin, fins, gills and eyes. }\end{array}$ \\
\hline
\end{tabular}

Source: Adapted from Mueller et al. (2017).

\subsection{Classification of Intensity of Mechanical Schocks}

We present the data collected by RMS value, average, maximum and minimum. The RMS (Root Mean Square) value or effective value is a statistical measure of the magnitude of the measured signal, for example that of vibration. Mathematically, it is expressed by:

$$
X_{R M S}=\sqrt{\frac{1}{N} \sum_{N=1}^{N}\left|X_{N}\right|^{2}}
$$

where, $x_{n}$ is the set containing the measured data; $x_{R M S}$ is the unique value representing a series of samples equally spaced in time; $N$ is the size of the data set.

From the RMS value on the three axes, we can calculate the resulting value by applying the square root of the sum of squares on each axis, Equation 2:

$$
R S S=\sqrt{R M S_{x}^{2}+R M S_{y}^{2}+R M S_{z}^{2}}
$$

\subsection{Statistical Evaluation}

The analyzes of the water, hematological and metabolic parameters of the fish before and after the vibratory stimulus and mechanical shocks during transportation were carried out using the software Bioestat 5.3. Initially the Kolmogorov-Smirnov test was applied to test the normality of the values obtained. Afterwards, the data were submitted to Analysis of Variance (ANOVA). When the value of $F$ indicated a significant difference $(p<0.05)$, the means were compared by the Tukey test. The results are presented as means \pm standard deviation in all analyzes.

\section{Results}

Of the fish followed during this research, after transport, one died, and another fish was not evaluated due to the detachment of the marking on the fin. In total, twenty-eight fish evaluated, with average weight (g) and average length $(\mathrm{cm})$, respectively, were $1100 \mathrm{~g}$ and $37 \mathrm{~cm}$. Mean temperature was obtained before and after, respectively 
$26.7^{\circ} \mathrm{C}$ and $24.9^{\circ} \mathrm{C}$. The mean dissolved oxygen rate of $11.5 \mathrm{mg} \mathrm{L}^{-1}$ and $8.7 \mathrm{mg} \mathrm{L}^{-1}$ e o pH between 7.28 and 5.40 , before and after transportation, reciprocally. The highest concentration of toxic ammonia $\left(\mathrm{NH}_{3}\right)$ recorded in the water analysis before and after, was mutually $0.12 \mathrm{mg} \mathrm{L}^{-1}$ and $0.07 \mathrm{mg} \mathrm{L}^{-1}$.

In all 28 samples analyzed, lesions in the caudal fins (35\%) and eyes with abnormal coloration (25\%) were the most frequently observed types of lesions, followed by head injuries (21\%), loose scales $(6 \%)$ and eyes $(3 \%)$ (Table 2). Regarding the metabolic and hematological responses, we observed a significant reduction in hematocrit, magnesium ions, as well as hemoglobin content (HCM), $p<0.05$. On the other hand, post-challenge stress led to a significant increase in total mean corpuscular volume (MCV) and plasma glucose levels $(\mathrm{p}<0.05)$ (Table 3).

Table 2. Distribution and frequency of agonistic physical lesions observed in tilapia (Oreochromis niloticus), after transportation

\begin{tabular}{lll}
\hline Agonistic physical lesions & Number of injured fishes $(\mathrm{n}=28)$ & Percentage of fish with lesions (\%) \\
\hline Caudal fin wounds & 10 & 35 \\
Dorsal fin injuries & 0 & 0 \\
Ventral fin wounds & 0 & 0 \\
Pectoral swimmer injuries & 0 & 0 \\
Skipped eyes & 1 & 3 \\
Eyes with abnormal coloring & 7 & 25 \\
Injured eyes & 0 & 0 \\
Loose scales & 2 & 6 \\
Sore head & 6 & 21 \\
\hline
\end{tabular}

Table 3. Mean \pm standard deviation of haematological and biochemical parameters $(n=28)$ of Nile Tilapia (Oreochromis Niloticus) before and after vibratory stimuli and mechanical shocks during transportation

\begin{tabular}{lll}
\hline Variables/Group & Before & After \\
\hline Erythrocytes $\left(10^{6} / \mathrm{mm} 3\right)$ & $1.49 \pm 0.31$ & $1.23 \pm 0.55$ \\
Hematocrit $(\%) *$ & $27.57 \pm 5.01$ & $24.85 \pm 4.59$ \\
Hemoglobin $\left(\mathrm{g} / \mathrm{dL}^{-1}\right) *$ & $9.81 \pm 3.15$ & $7.93 \pm 2.34$ \\
VCM1 $(\mathrm{fL}) *$ & $190.58 \pm 41.53$ & $234.52 \pm 95.47$ \\
HCM2 $(\mu \mathrm{g})$ & $66.21 \pm 22.83$ & $78.81 \pm 38.26$ \\
CHCM3 $\left(\mathrm{g} \mathrm{dL}^{-1}\right)$ & $35.63 \pm 14.24$ & $32.23 \pm 8.63$ \\
Chloride $\left(\mathrm{mmol} \mathrm{L}^{-1}\right)$ & $117.20 \pm 26.34$ & $99.30 \pm 26.30$ \\
Magnesium $\left(\mathrm{mmol} \mathrm{L}^{-1}\right) *$ & $2.63 \pm 0.55$ & $1.68 \pm 0.50$ \\
Glucose $\left(\mathrm{g} \mathrm{dL}^{-1}\right) *$ & $75.57 \pm 24.78$ & $95.53 \pm 27.43$ \\
PPT4 $\left(\mathrm{g} \mathrm{dL}^{-1}\right)$ & $3.03 \pm 1.18$ & $2.46 \pm 0.84$
\end{tabular}

Note. (1) $\mathrm{VCM}=$ Mean corpuscular volume; (2) $\mathrm{HCM}=$ Mean corpuscular haemoglobin; (3) $\mathrm{CHCM}=$ Mean corpuscular hemoglobin concentration; (4) PPT = Total Plasma Protein; * differed from each other $(\mathrm{P}<0.05)$ by Tukey's test.

\section{Discussion}

Regarding the limnological parameters, only the $\mathrm{pH}$ was found in an uncomfortable range for fish, according to Boyd and Tucker (1998), but not lethal. Tilapia withstand well pH between 5 and 9, below and above these values, have low survival and lower developmental rates (Barbosa, 2007). The decrease in $\mathrm{pH}$ was already expected due to the respiration of the fish, resulting in the release of $\mathrm{CO}_{2}$ and consequent acidification of the environment (Moreira et al., 2015). There was no statistical difference between treatments (transport box before and after) $(\mathrm{p}>0.05)$ throughout the experimental period. Although aggressive interactions are part of the fish's natural behavior and are constant and intense, such interactions can cause serious damage, increase energy expenditure and cause animals to suffer from social stress. Despite these behavioral variations, all cichlid species, especially Nile tilapia, a territorial species, are marked by aggressions (mouth/mouth bites, mouth/side, mouth/tail) and by signs such as threats and other exhibits (Wolff \& Donatti, 2016; Gonçalves-de-Freitas et al., 2019). 
It was observed that $21 \%$ of the samples had severe lesions in the integuments and $34 \%$ had moderate lesions. Barreto et al. (2015), found a similar result for Nile tilapia, a Thai strain, in which fish presented increased lesions and loss of scales when grouped according to their size. There are also incidental traumatic events that significantly reduce the survival capacity of the fish. In this way, a mechanical shock of a fish against a hard surface can traumatize various parts of its body (Texeira Filho, 1991). The analysis of similarity of the lesions is extremely relevant to verify which are the alterations that have some type of relation between them according to the degree of severity and with the environmental characteristics (Oliveira et al., 2016). Pigment abnormalities can cause physical damage and fish mortality. This can also result from the severe loss of body protection against infections, and reduced swimming performance (Vernerey \& Barthelat, 2010; Noble et al., 2012, Dastjerdi \& Barthelat, 2015).

In the present study, the effect of glycemic index on the glycemic index of the fish in the diet was significantly higher than in the control group. Thus, the increase in the glycemic values of the fish exposed to the proposed challenge may have occurred by the stimulation of the catecholamines, mobilizing the increase to glycogenolysis, in order to generate energy for a fast action of the animals to a stressor agent (Moreira et al., 2011). In the present study, the effect of glycemic index on the glycemic index of the fish in the diet was significantly higher than in the control group. Thus, the increase in the glycemic values of the fish exposed to the proposed challenge may have occurred by the stimulation of the catecholamines, mobilizing the increase to glycogenolysis, in order to generate energy for a fast action of the animals to a stressor agent (Moreira et al., 2011). In the present study, plasma glucose fluctuated after transient vibration from 75.57 to $95.53 \mathrm{mg} \mathrm{dL}^{-1}$, within the range previously reported for Nile tilapia, from 45 to $130 \mathrm{mg} \mathrm{dL}^{-1}$ (Gonçaves-de-Freitas et al., 2019; Keller-Costa et al., 2015; Volpato \& Fernandes, 1994), and for other species, from 40 to $110 \mathrm{mg} \mathrm{dL}^{-1}$ (Damsgard \& Huntingford, 2002). However, the higher the concentration of this sugar in the blood, the greater the stressful condition of the animal (Eslamloo et al., 2014). Glucose elevation was also observed in tilapia after fish were submitted to other stressors (Moreira et al., 2015; Navarro et al., 2016).

Post-transport hyperglycemia results in part by the stimulation of catecholamine glycogenolysis to meet the increasing demands of energy in response to stress. In addition, catecholamines work to regulate some cardiovascular and respiratory functions, including increased blood flow, gill permeability, and lamellar recruitment. The resulting increase in gas exchange also increases gill permeability to water and some ions. This may be manifested as water gain and loss of blood ions from freshwater fish and as water loss and influx of ions to marine fish. However, for this osmoregulation to occur, it is necessary to increase energy consumption by the fish. In order to control energy expended with osmoregulation, tilapias mobilize energy reserves and direct them to other functions of the organism (Rodrigues et al., 2018; Portz, Woodley \& Cech Junior, 2006). Osmoregulatory disorders can be stress-induced. The ionic regulation, maintaining the concentrations of the fluids in certain limits, can be used as a measure of stress, the extrapolation of these limits being a stressful situation (Moreira et al., 2015). In teleosts, electrolyte levels may vary with species and environment. For fish cultured in tropical climate, plasma magnesium levels are approximately 0.5 to $2.8 \mathrm{mmol} \mathrm{L}^{-1}$ and chloride of 58.0 to $193.0 \mathrm{mmol} \mathrm{L}^{-1}$ (Tavares-Dias, Bozzo, Sandrin, Campos-Filho, \& Moraes, 2004). Chloride levels did not show any significant changes in fish submitted to mechanical transport stimuli. The mean chloride contents were lower $(\mathrm{p}>0.05)$ when compared to the control group $\left(117.20 \pm 26.34 \mathrm{mmol} \mathrm{L}^{-1}\right)$.

The amount of magnesium in the plasma of the adults of tilapia before transport showed, on average, $2.63 \pm 0.55$ $\mathrm{mmol} \mathrm{L}{ }^{-1}$. After the average of three hours of transport, the fish sampled reduced the $\mathrm{Mg}^{2+}$ ion content, differing statistically $(\mathrm{p}<0.05)$ in relation to the control, reaching $1.68 \pm 0.50 \mathrm{mmol} \mathrm{L}^{-1}$. Indicating that the animals could not maintain the initial homeostasis. Iversen et al. (2009) submitted salmon salmon, with a mean weight of 71.8 $\mathrm{g}$ to the transport, also observed that immediately after the imposed challenge, there was a significant increase in fish plasma magnesium compared to the control group (before transport).

There was a significant increase $(\mathrm{p}<0.05)$ in the values obtained from the hematimetric indexes of the Mean Corpuscular Volume (234.52 $\pm 95.47 \mathrm{fL}$ ) when comparing with the values of the control group (190.58 $\pm 41.53 \mathrm{fL})$. The values were higher for the values described in tilapia by Tran-Duy et al. (2008) $111 \mathrm{fL}$ and Nagata et al. (2009) $106 \mathrm{fL}$; while CHCM values of $32.23 \mathrm{~g} \mathrm{dL}^{-1}$ were lower or similar to those found by Bittencourt et al. (2003) $35.2 \mathrm{~g} \mathrm{dL}^{-1}$; Tran-Duy et al. (2008) $40 \mathrm{~g} \mathrm{dL}^{-1}$; Nagata et al. (2009) 27 to $33 \mathrm{~g} \mathrm{dL}^{-1}$ in tilapia. This increase suggests that the tilapias sought to adapt to the adverse situations of high densities and expense. According to other authors, biological, physiological, behavioral and environmental factors may influence the variation of hematological parameters, such as the hemoglobin level, since there is a correlation between both, Medium Corpuscular Volume and Hemoglobin. These parameters are related to fish activity and habitat, as well as nutritional characteristics (Azevedo et al. 2016). 
Hemoglobin, the respiratory pigment of erythrocytes, has the function of transporting $\mathrm{O}_{2}$ and part of $\mathrm{CO}_{2}$ into the blood (Ranzani-Paiva \& Silva-Souza, 2004). Hemoglobin exhibits differences still in relation to its buffering capacity and variations in oxygen affinity (Val et al., 1996). Paiva et al. (2000) determined 7.3 to $9.7 \mathrm{~g} \mathrm{dL}^{-1}$ for migratory species and other authors recorded $6.6 \mathrm{~g} \mathrm{dL}^{-1}$ and $13 \mathrm{~g} \mathrm{dL}^{-1}$ for other species (Azevedo et al., 2016). Although the values found before and after the transport were within the expected values for the species, the hemoglobin concentration presented a significant reduction $(\mathrm{p}<0.05)$ after the environmental challenge presented, vibrations and mechanical shocks. The erythropoietic activities related to the number of erythrocytes, hemoglobin concentration and Mean Corpuscular Volume (GV) are indicators of the capacity of oxygen transport, hypoxia, exercise, induced stress, reproductive stage and seasonal variations (Tavares-Dias \& Moraes, 2004). Therefore, any deficiency in the number of erythrocytes or hemoglobin concentration may reflect a lack of $\mathrm{O}_{2}$ in the tissues and impair the proper functioning of the cells (Ranzani-Paiva \& Silva-Souza, 2004).

Mean values of erythrocyte numbers (RBC), although not significant ( $p>0.05)$, presented values lower than the control treatment $\left(1.49 \pm 0.31 \times 10^{6} \mathrm{~mm}^{-3}\right)$, prior to transport. The mean number of total erythrocytes was similar to the values found by Azevedo et al. (2006) $1.5 \times 10^{6} \mu \mathrm{L}$ and lower than Ighwela et al. (2012) $4.3 \times 10^{6} \mu \mathrm{L}$. Red blood cell count (RBC) and hematocrit are tools used to diagnose stressful conditions in fish. Both parameters are studied in an associated way, where the hematocrit represents the concentration of red blood cells per blood volume and is expressed in percentage (Grant, 2015).

Hematocrit may change due to other causes, such as increased erythropoietic activity of the spleen and the stress kidney, while nutrient deficiency depresses the production of erythrocytes, thrombocytes and leukocytes. Hematocrit changes through stress cause hemoconcentration or hemodilution; in hemoconcentration may be by the release of erythrocytes by the spleen; in hemodilution the reduction in hematocrit values (Silva et al., 2012). In the present study, after the transport stimulus, there was a reduction $(p<0.05)$ when compared to the control group, prior to transportation $(27.57 \pm 5.01 \%)$. The percentage of hematocrit is the index that presents the lowest variation among tilapia, remaining between 25.6 and $33.7 \%$. Due to the fact that hematocrit is the index of erythrogram with lower coefficient of variation in $O$. niloticus, it can be considered an indicator of the actions caused to fish by environmental factors (Lewandowski et al. 2015). The decrease in hematocrit is associated with chronic stress in fish (Barcellos et al., 2004). Orji (2005) also mentioned the significant reduction in the hematocrit level of the Nile tilapia (Linnaeus) due to transport stress. The stress of transport and acclimatization to the new environment, such as handling and the moderate and severe physical injuries encountered, are likely to damage the mucous or lime layer surrounding the fish. Under this circumstance, being a freshwater species, it absorbs a large part of the acclimatization water and contributes substantially to the reduction of the hematocrit (Okafor \& Achilefu, 2017; Meges et al., 2015).

Total plasma protein has been frequently used to elucidate the health status and mechanisms of the biological metabolism of animals under environmental stressors (Cheng et al., 2017), since they have fundamental roles in the physiological and immunological systems and are the main components of serum (Kumar et al., 2005), its decrease may be indicative of physiological deficiency (Moreira et al., 2015). Mean plasma protein reference values for healthy tilapia were averaged between 3.0 and $7.7 \mathrm{~g} \mathrm{dL}^{-1}$ (Araujo et al., 2015). According to Table 4, the total protein concentration in the plasma was not significantly influenced $(p>0.05)$ in the animals after the vibratory stimulus throughout the experimental period. On the other hand, fish after transport maintained the concentration close to the Control Group level $\left(3.03 \pm 1.18 \mathrm{~g} \mathrm{dL}^{-1}\right)$, dropping to $2.46 \pm 0.84 \mathrm{~g} \mathrm{dL}^{-1}$ when they were sampled. The organisms obtained lower mean values of total plasma protein concentration, compared to the fish sampled before the vibratory stimuli and below the healthy level for the species. This same behavior was investigated by Eslamloo et al. (2014) by subjecting Carassius auratus to acute stress.

We will discuss below the data related to the vibration signal. After analyzing the signal collected with the dataloggers, a correlation was observed between the speed of the truck and the intensity of the mechanical shocks. We can see that the occurrence of mechanical shocks accompanies the increase in speed (Figure 3). The quality of the roads contributes directly to the occurrence of these impacts that are propagated throughout the structure of the truck until the transport boxes arrive. Thus, deformations in the asphalt, holes, spines have effect amplified depending on the speed at which the truck is driven. In general, the strongest mechanical shocks occurred in the $\mathrm{X}, \mathrm{Z}$ and $\mathrm{Y}$ axes, respectively in descending order of intensity. 


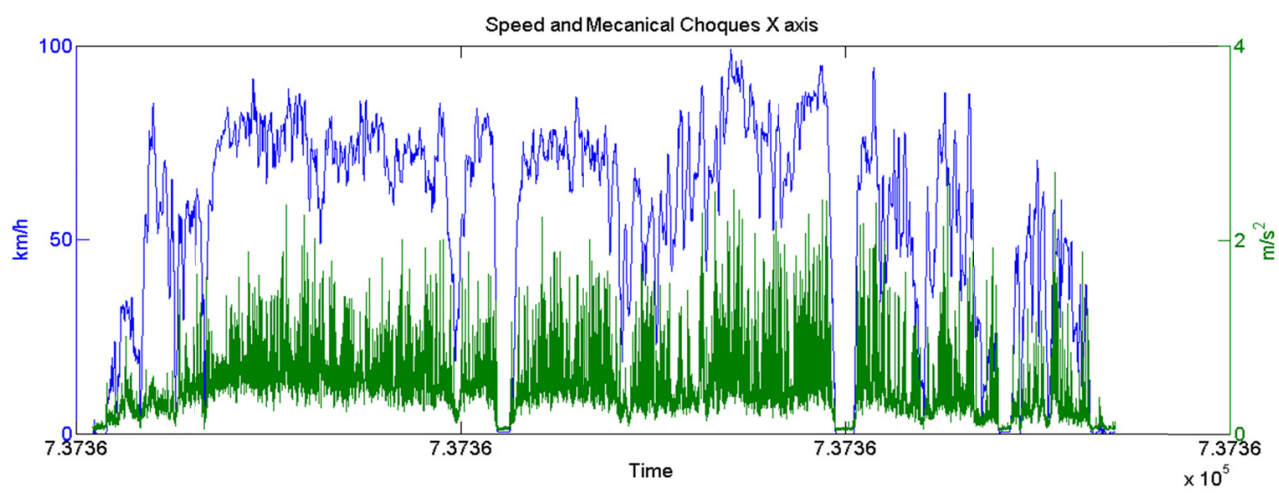

(a)

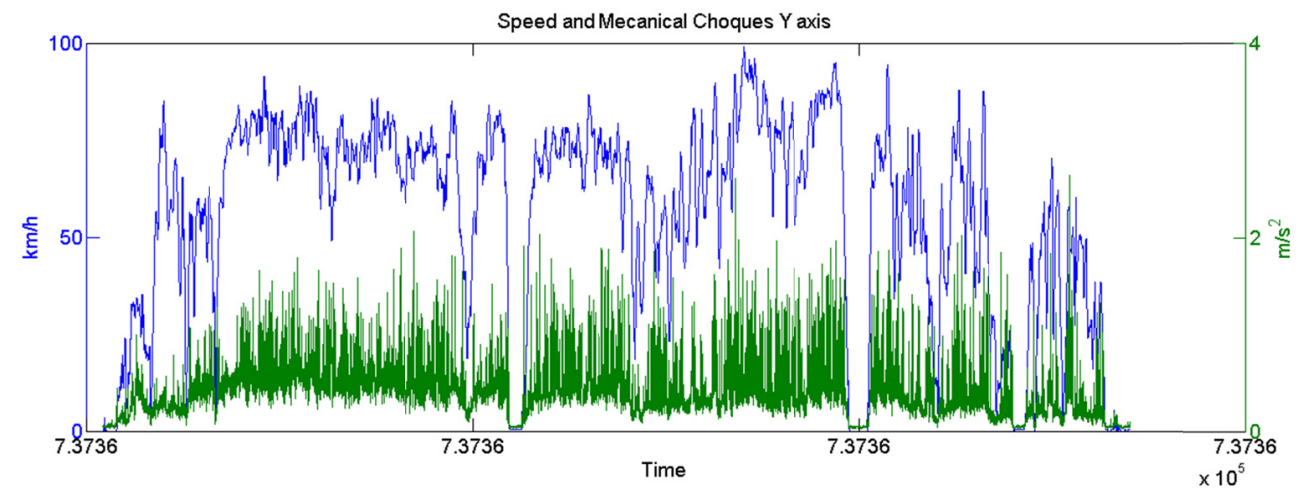

(b)

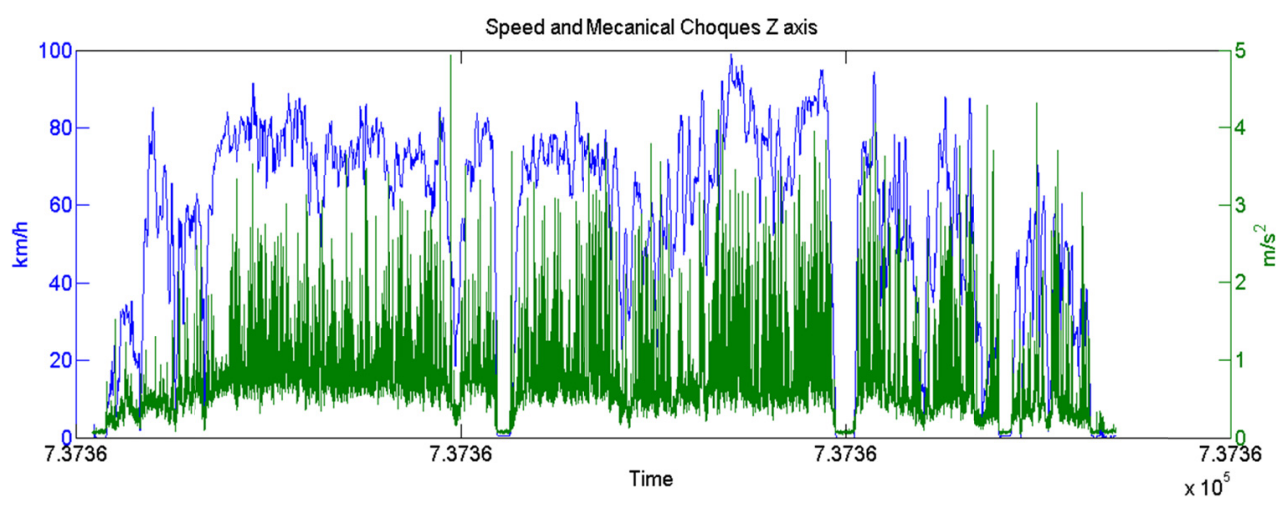

(c)

Figure 3. Behavior of truck speed and occurrence of mechanical shocks; (a) axis X, (b) axis Y and (c) axis Z, of the accelerometer sensor

The mechanical shocks were divided into levels according to the intensity and speed of the truck at the moment of occurrence, shown in Figure 4. As a reference we use International Organization for Standardization (ISO) 2631-1, which deals with a study carried out to evaluate human exposure to whole body vibrations. This standard considers four important factors to determine the human response to vibration, namely: intensity, frequency, direction and duration, which includes the time of exposure to certain levels of vibration. The reference value adopted was $0.315 \mathrm{~m} \mathrm{~s}^{-2}$, the same used by Nazareno et al. (2015) and considered for transport duration up to 8 hours. Let's look at Figure 4. The graphs depicted by color show the mechanical shocks perceived by each axis of the accelerometer. We observed by analyzing the samples in the three axes that there is a correlation between speed and intensity of shocks. The most intense shocks occurred more frequently with the truck moving above $40 \mathrm{~km} \mathrm{~h}^{-1}$. In the X-axis (Figure 4a) we noticed the significant occurrence of shocks with intensity $10.08 \mathrm{~m} \mathrm{~s}^{-2}$, 32 times higher than the norm cited for humans, followed by shocks of lower intensity. In the $\mathrm{Y}$ and $\mathrm{Z}$ axes (Figures $4 \mathrm{~b}$ and $4 \mathrm{c}$ ) there was a significant occurrence of shocks with an intensity of $5.04 \mathrm{~m} \mathrm{~s}^{-2}, 16$ times higher than the norm recommended, followed by shocks of lower intensity. 


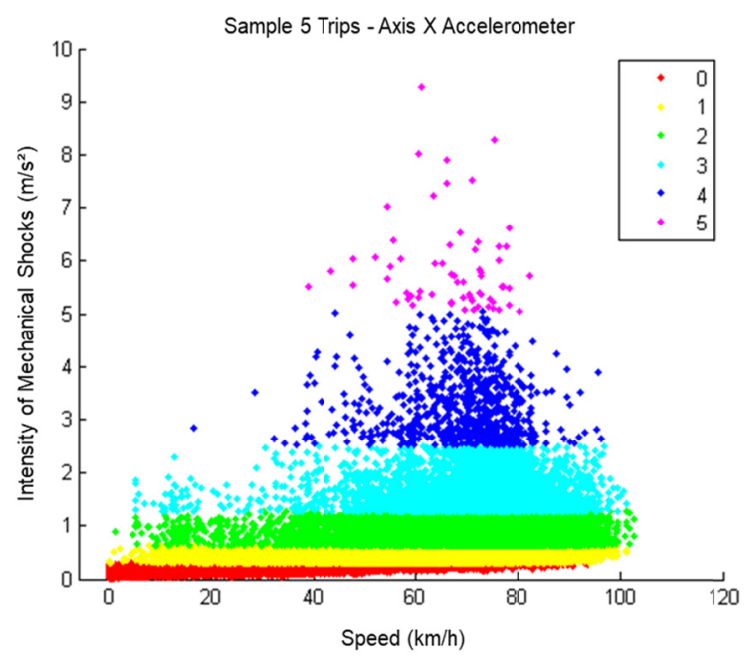

(a)

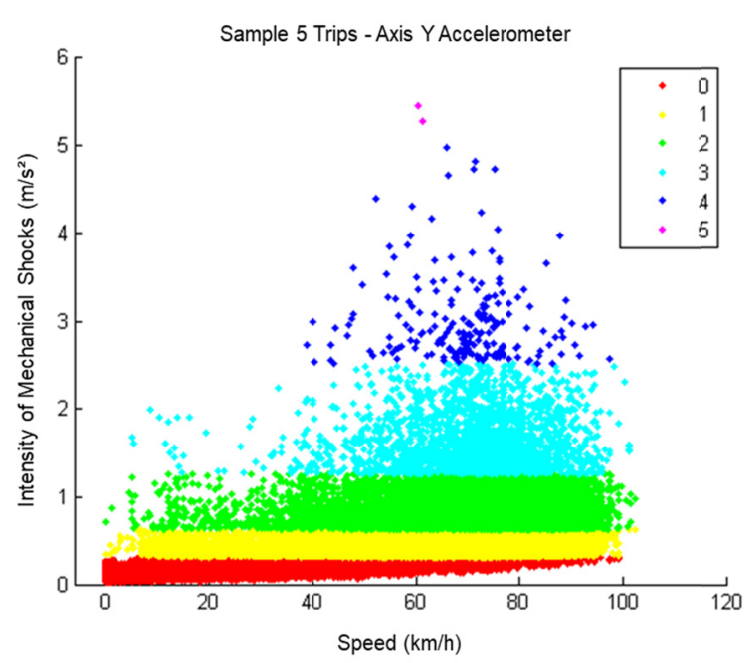

(b)

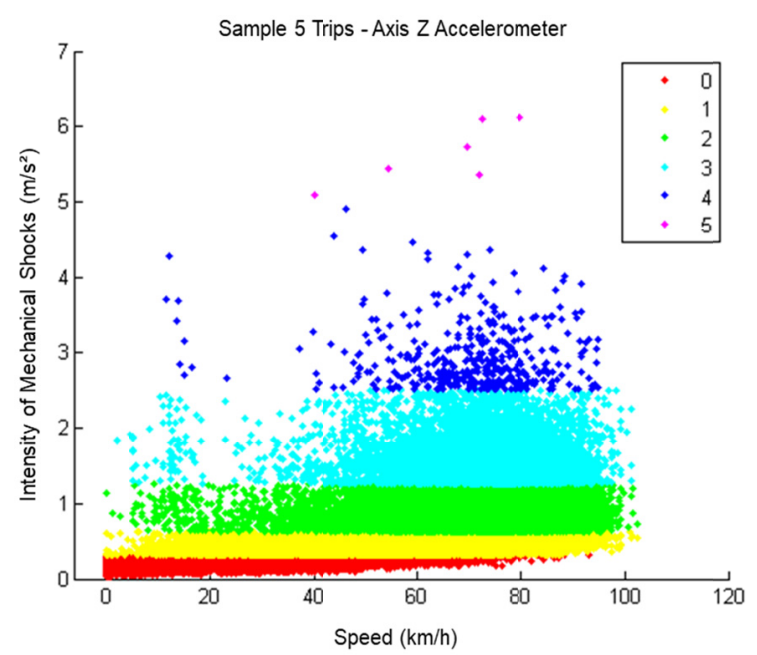

(c)

Figure 4. Visualization of the samples referring to the occurrence of mechanical shocks, considering the parameters speed and intensity

In Figure 5 we show the amount of the mechanical shocks considering the intensity in relation to the average effective value, RMS. The highest observed occurrence included shocks up to ten times higher than the average calculated on all trips. To compare the magnitude of the vibration in the tank structure with the magnitude of the vibration felt by the fish in the water, the P05 data were used. This equipment was placed in a float inside the tank, in order to measure the vibration propagated in the water. 


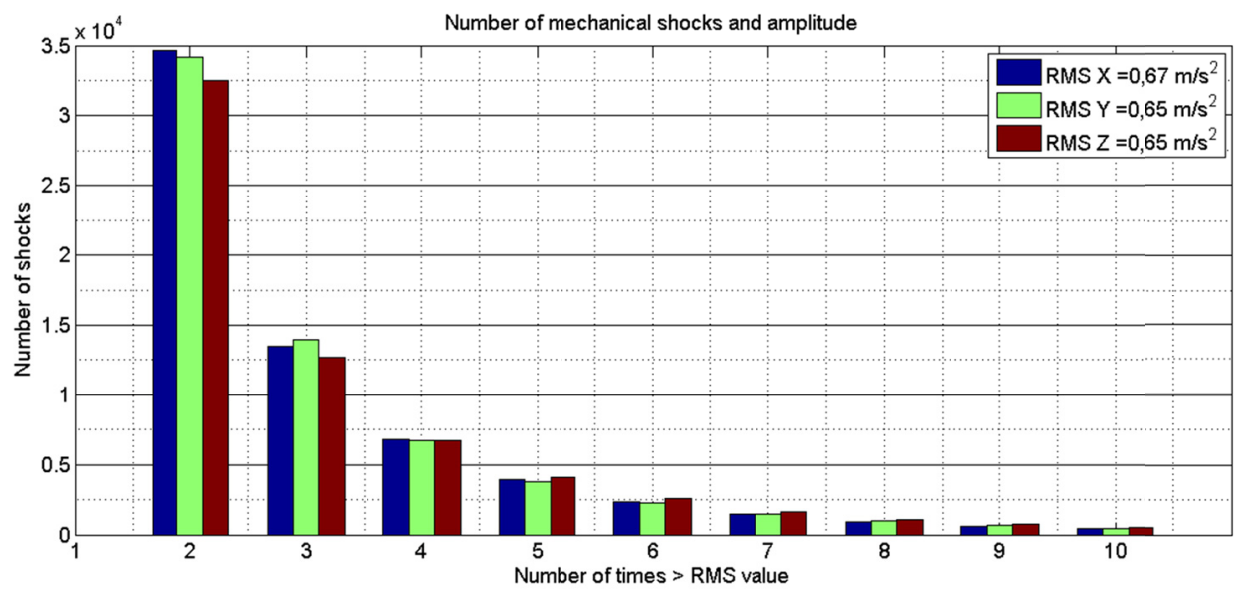

Figure 5. Occurrence of mechanical shocks and comparative with the intensities relative to the average effective RMS in the $\mathrm{X}, \mathrm{Y}$ and $\mathrm{Z}$ axes

In Table 4 we present the vibration values calculated from the data of the five trips. For purposes of comparison, we separate the routes on land, asphalt, and the complete route land and asphalt. In the tank structure the resulting RSS was higher considering the complete route $\left(1.151 \mathrm{~m} \mathrm{~s}^{-2}\right)$ and lower on the dirt road $\left(0.574 \mathrm{~m} \mathrm{~s}^{-2}\right)$. The vibration measured in the water was higher in the earth path $\left(0.515 \mathrm{~m} \mathrm{~s}^{-2}\right)$ and smaller in the complete path $\left(0.489 \mathrm{~m} \mathrm{~s}^{-2}\right)$, with values very close. It is noteworthy that on the dirt road the truck traveled with an average speed of $20.39 \mathrm{~km} \mathrm{~h}^{-1}$, while on the asphalt the measured speed was higher, approximately $57 \mathrm{~km} \mathrm{~h}^{-1}$. As expected, the perceived vibration in the water was smaller than in the tank structure, since the water acts as a vibration damping agent. But not enough to avoid the effects that this causes to living organisms transported.

Table 4. Vibration values for the record made during the five trips

\begin{tabular}{|c|c|c|c|c|c|c|c|c|c|c|c|}
\hline \multirow{3}{*}{ Types of road } & & \multicolumn{8}{|c|}{ Acceleration vibration levels $\left(\mathrm{m} \mathrm{s}^{-2}\right)$} & \multirow{3}{*}{$\begin{array}{l}\text { Velocity } \\
\text { average truck } \\
(\mathrm{km} / \mathrm{h})\end{array}$} & \multirow{3}{*}{$\begin{array}{l}\text { Duration } \\
\text { of transport } \\
\text { (hour: minute) }\end{array}$} \\
\hline & & \multicolumn{4}{|c|}{ Tank structure (P01 to P04) } & \multicolumn{4}{|c|}{ In the water (P05) } & & \\
\hline & & $\mathrm{X}$ & $\mathrm{Y}$ & $\mathrm{Z}$ & RSS & $\mathrm{X}$ & $\mathrm{Y}$ & $\mathrm{Z}$ & RSS & & \\
\hline \multirow{3}{*}{ Dirt } & RMS & 0.308 & 0.363 & 0.316 & & 0.289 & 0.293 & 0.307 & & 20.29 & \\
\hline & $\operatorname{Max}(+)$ & 4.736 & 4.458 & 5.341 & 0.574 & 9.686 & 10.696 & 5.554 & 0.515 & 38.39 & 00:06 \\
\hline & $\operatorname{Min}(-)$ & 4.409 & 4.783 & 2.304 & & 8.885 & 7.979 & 9.948 & & 0.00 & \\
\hline \multirow{3}{*}{ Asphalt } & RMS & 0.644 & 0.659 & 0.657 & & 0.233 & 0.253 & 0.326 & & 57.79 & \\
\hline & $\operatorname{Max}(+)$ & 12.445 & 13.361 & 13.47 & 1.136 & 11.818 & 15.225 & 11.148 & 0.475 & 99.01 & 03:10 \\
\hline & $\operatorname{Min}(-)$ & 15.273 & 13.194 & 14.195 & & 13.156 & 19.292 & 13.852 & & 0.00 & \\
\hline \multirow{3}{*}{ Dirt and asphalt } & RMS & 0.674 & 0.655 & 0.656 & & 0.243 & 0.262 & 0.331 & & 57.48 & \\
\hline & $\operatorname{Max}(+)$ & 14.559 & 13.896 & 14.200 & 1.151 & 13.743 & 17.192 & 11.548 & 0.489 & 99.18 & 03:04 \\
\hline & $\operatorname{Min}(-)$ & 15.771 & 14.874 & 15.209 & & 13.854 & 20.123 & 14.256 & & 0.00 & \\
\hline
\end{tabular}

\section{Conclusion}

The frequency and severity of the agonistic physical lesions of the fish, with $34 \%$ severe and $21 \%$ moderate, after transportation showed high interconnection with the haematological parameters found. Thus, fish presented secondary responses to stress at blood level with changes in glycemia, hematocrit, hemoglobin and magnesium ions, when compared to the control group, prior to transportation. In this way, we can infer that the shocks and mechanical vibrations quantified in this work may have contributed to the stress of the organisms sampled. Therefore, it is recommended for transport and pre-slaughter operations of Nile tilapia, do not exceed the speed limits of $60 \mathrm{~km} \mathrm{~h}^{-1}$ and consequently traffic at levels below that found in this study, vibrations $1.151 \mathrm{~m} \mathrm{~s}^{-2}$ in the transport, as well as in the water $0.489 \mathrm{~m} \mathrm{~s}^{-2}$. We also suggest, if possible, better cushion the transport boxes by inserting springs into the boxes in order to reduce the effect of mechanical shocks. 


\section{References}

Alvarenga, C. M. D., \& Volpato, G. L. (1995). Agonistic profile and metabolism in alevins of the Nile tilapia. Physiology and Behavior, 57(1), 75-80. https://doi.org/10.1016/0031-9384(94)00206-k

Alves, A. R., Figueiredo Júnior, R. P., Santana, M. H. M., Andrade, M. V. M., Lima, J. B. A., Pinto, L. S., \& Ribeiro, L. de M. (2016). Effect of stress on the quality of products of animal origin. Publicações em Medicina Veterinária e Zootecnia, 10(6), 448-459. https://doi.org/10.22256/pubvet.v10n6.448-459

Araujo, D. M., Junior, A. C. F., Teixeira, C. P., Pezzato, L. E., \& Barros, M. M. (2015). Hematological profile of Nile tilapia fed diets containing different lipids and stimulated by low temperature. Revista Caatinga, 28(1), 220-227. https://doi.org/10.1590/S1516-35982010000800001

Azevedo, T. M. P., Albinati, R. C. B., Guerra-Santos, B., Pinto, L. F. B., Lira, A. D., Medeiros, S. D. C., \& Ayres, M. C. C. (2016). Reference values of the hematological parameters of Oreochromis niloticus (Linnaeus, 1758) grown in net tanks in Paulo Afonso, Bahia State, Brazil. Brazilian Journal of Aquatic Science and Technology, 20(2), 63-74. https://doi.org/10.14210/bjast.v20n2.4588

Azevedo, T. M. P., Martins, M. L., Yamashita, M. M., \& Francisco, C. J. (2006). Hematology of Oreochromis niloticus: comparison between fish kept in pisciculture with swine and fish paid in the Tijucas River Valley, Santa Catarina, Brazil. Boletim Instituto da Pesca, 32(1), 41-49. https://doi.org/10.1590/S1519-99402015 000400018

Barbosa, A. C. A. A. (2007). Creation of Tilapia in Cages. EMPARN (Empresa de Pesquisa Agropecuária do Rio Grande do Norte), Lagoa Nova, RN.

Barcellos, J. G. B., Kreutz, L. C., De Souza, C., Rodrigues, L. B., Fioreze, I., Quevedo, R. M., ... Terra, S. (2004). Hematological changes in jundiá Rhamdia quelen Quoy and Gaimard Pimelodidae) after acute and chronic stress caused by usual aquacultural management, with emphasis on immunosuppressive effects. Aquaculture, 237, 229-236. https://doi.org/10.1016/j.aquaculture.2004.03.026

Barreto, T. N., Boscolo, C. N. P., \& Gonçalves-de-Freitas, E. (2015). Homogeneously Sized Groups Increase Aggressive Interaction and Affect Social Stress in Thai Strain Nile Tilapia (Oreochromis niloticus). Marine Behaviour and Physiology, 48(5), 309-318. https://doi.org/10.1080/10236244.2015.1070478

Bittencourt, N. L. R., MolinarI, L. M., Scoaris, D. O., Pedroso, R. B., Nakamura, C. V., Nakamura, T. U., ... Dias Filho, B. P. (2003). Haematological and biochemical values for Nile tilápia Oreochromis niloticus cultured in semi-intensive system. Acta Scientiarum. Biological Sciences, 25(2), 385-389. Retrieved from $\mathrm{http} / / /$ citeseerx.ist.psu.edu/viewdoc/download?doi=10.1.1.634.6424\&rep=rep1\&type=pdf

Boyd, C. E., \& Tucker, C. S. (1998). Pond aquaculture water quality management (p. 700). Boston: Kluwer Academic Publishers. https://doi.org/10.1007/978-1-4615-5407-3

Cheng, C. H., Ye, C. X., Guo, Z. X., \& Wang, G. A. L. (2017). Immune and physiological responses of pufferfish (Takifugu obscurus) under cold stress. Fish \& Shellfish Immunology, 64, 137-145. https://doi.org/10.1016/ j.fsi.2017.03.003

Collier, H. B. (1944). The standardization of blood haemoglobin determinations. Canadian Medical Association Journal, 50, 550-552. Retrieved from http://www.ncbi.nlm.nih.gov/pmc/articles/PMC1581573/pdf/ canmedaj00573-0133.pdf

Damsgard, B., \& Huntingford, F. (2002). Fighting and Aggression. In F. Huntingford, M. Jobling, \& S. Kadri (Eds.), Aquaculture and Behavior (p. 340). Wiley-Blackwell: Oxford, UK.

Dastjerdi, A. K., \& Barthelat, F. (2015). Teleost fish scales amongst the toughest collagenous materials. Journal of Mechanical Behavior of Biomedical Materials, 52, 95-107. https://doi.org/10.1016/j.jmbbm.2014.09.025

Eslamloo, K., Akh Avan, S. R., Fallah, F. J., \& Henry, M. A. (2014). Variations of physiological and innate immunological responses in goldfish (Carassius auratus) subjected acute stress. Fish \& Shellfish Immunology, 37, 147-153. https://doi.org/10.1016/j.fsi.2014.01.014

FAO. (2018). The State of World Fisheries and Aquaculture 2018. Rome, Italy.

Gebresenbet, G., Aradom, S., Bulitta, F. S., \& Hjerpe, E. (2011). Vibration levels and frequencies on vehicle and animals during transport. Biosystems Engineering, 110(1), 10-19. https://doi.org/10.1016/j.biosystemseng. 2011.05.007 
Goes, E. S. R., Lara, J. A. F., Gasparino, E., Goes, M. D., Zuanazzi, J. S. G., Lopera-Barrero, N. M., ... Ribeiro, R. P. (2018). Effects of transportation stress on quality and sensory profiles of Nile tilapia fillets. Scientia Agricola, 75(4), 321-328. https://doi.org/10.1590/1678-992x-2016-0387

Goldenfarb, P. B., Bowyer, F. P., Hall, E., \& Brosius, E. (1971). Reproducibility in the hematology laboratory: The microhematocrit determination. American Journal of Clynical Pathology, 56(1), 35-39. https://doi.org/ 10.1093/ajcp/56.1.35

Gonçalves-de-Freitas, E., Bolognesi, M. C., Gauy, A. C. S., Brandão, M. L., Giaquinto, P. C., \& Fernandes-Castilho, M. (2019). Social Behavior and Welfare in Nile Tilapia. Fishes, 4(2), 23. https://doi.org/10.3390/fishes4020023

Grant, K. R. (2015). Fish Hematology and Associated Disorders. Fish Hematology and Associated Disorders, Veterinary Clinics of North America: Exotic Animal Practice, 18(1), 83-103. https://doi.org/10.1016/ j.cvex.2014.09.007

Ighwela, K. A., Ahmad, A. B., \& Abol-Munaf, A. B. (2012). Haematological Changes in Nile Tilapia (Oreochromis niloticus) Fed with Varying Dietary Maltose Levels. World Journal of Fish and Marine Sciences, 4(4), 376-381. https://doi.org/10.5829/idosi.wjfms.2012.04.04.61297

ISO 2631-1. (1997). Mechanical vibration and shock-Evaluation of human exposure to whole-body vibration. Part 1: General requirements (p. 31). Geneva.

Iversen, M., Eliassen, R. A., \& Finstad, B. (2009). Potential benefit of clove oil sedation on animal welfare during salmon smolt, Salmo salar L. transport and transfer to sea. Aquaculture Research, 40(2), 233-241. https://doi.org/10.1111/j.1365-2109.2008.02091.x

Jain, N. C. (1986). Schalm's veterinary haematology (4th ed., p. 1221). Philadelphia: Lea e Febiger.

Keller-Costa, T., Canário, A. V. M., \& Hubbard, P. C. (2015). Chemical Communication in Cichlids: A Mini-Review. General and Comparative Endocrinology, 221, 64-745. https://doi.org/10.1016/j.ygcen. 2015.01 .001

Lewandowski, V., Fries, E. M., Pessini, J. E., Signor, A., Feiden, A., \& Boscolo, W. R. (2015). Vitamina A em dietas para juvenis de tilápia do Nilo. Revista Agrarian, 8(28), 196-203. Retrieved from http://ojs.ufgd.edu.br/index.php/agrarian/article/view/2823/2414

Mendes, J. M., Inoque, L. A. K. A., \& Jesus, R. S. de. (2015). Influence of stress caused by transport and method of slaughter on tambaqui (Colossoma macropomum) rigor mortis, Brazilian Journal of Food Technology, 18(2), 162-169. https://doi.org/10.1590/1981-6723.1115

Mendonça, F. S., Vaz, R. Z., Costa, O. A. D., Gonçalves, G. V. B. E., \& Moreira, S. M. (2016). Factors affecting the welfare of cattle during the pre-slaughter period. Archivos de Zootecnia, 65(250), 279-287. https://doi.org/10.21071/az.v65i250.500

Miranda de La Lama, G. C., Villarroel, M., \& Maria, G. A. (2014). Livestock transport from the perspective of the pre-slaughter logistic chain: A review. Meat Science, 98(1), 9-20. https://doi.org/10.1016/j.meatsci. 2014.04.005

Moreira, A. G. L., Coelho, A. A. C., Albuquerque, L. F. G., Moreira, R. T., \& Farias, W. R. L. (2015). Efeito do eugenol como agente mitigador do estresse no transporte de juvenis de tilápia do Nilo. Pesquisa Veterinária Brasileira, 35(11), 893-898. https://doi.org/10.1590/S0100-736X2015001100004

Moreira, A. G. L., Teixeira, E. G., Moreira, R. L., \& Farias, W. R. L. (2011). Glicose plasmática em juvenis de tilápia do Nilo anestesiados com óleo de cravo. Revista Brasileira de Saúde e Produção Animal, 12(3), 794-804. http://revistas.ufba.br/index.php/rbspa/article/view/2083/1147

Mueller, M., Pander, J., \& Geist, J. (2017). Evaluation of external fish injury caused by hydropower plantsbased on a novel field-based protocol. Fisheries Management and Ecology, 24(3), 240-255. https://doi.org/ 10.1111/fme.12229

Nagata, M. M., Zanuzzo, F. S., Saita, M. V., Biller, J. da B., Urbinati, E. C., \& Takahashi, L. S. (2009). Efeito da perseguição e exposição aérea nos parâmetros hematológicos de juvenis de tilápia-do-Nilo. V Simpósio de Ciências da UNESP e VI Encontro de Zootecnia, UNESP Dracena, 22 a 24 de Setembro de 2009.

Navarro, F. K. S. P., \& Navarro, O, R. D. (2017). Importância das cores no crescimento, bem-estar e reprodução de peixes. Arquivos Ciências Veterinárias e Zoologia, 20(1), 45-48. https://doi.org/10.25110/arqvet. v20i1.2017.6320 
Navarro, R. D., França, R. P. de, Paludo, G. R., Wlademir, Y., Bizarro, S., Silva, R. F. da, \& Navarro, F. K. S. P. (2016). Physiological and hematological responses of Nile tilápia (Oreochromis Niloticus) to different anesthetics during simulated transport conditions. Acta Scientiarum. Technology, 38(3), 301-306. https://doi.org/10.4025/actascitechnol.v38i3.28377

Nazareno, A. C., da Silva, I. J. O., Donofre, A. C., Vieira, M. C. F., \& Castro, A. C. (2015). Vibrações e choques mecânicos em pintos de um dia transportados em diferentes estradas. Revista Brasileira de Engenharia Agricola e Ambiental, 19(7), 680-685. https://doi.org/10.1590/1807-1929/agriambi.v19n7p680-685

Niedźwiedź, A., Kubiak, K., \& Nicpoń, J. (2013). Plasma total antioxidant status in horses after 8-hours of road transportation. Acta Veteterinaria Scandinavica, 55, 2-4. https://doi.org/10.1186/1751-0147-55-58

Noble, C., Jones, H. A., Damsgård, B., Flood, M. J., Midling, K. Ø., Roque, A., ... Cottee, S. Y. (2012). Injuries and deformities in fish: Their potential impacts upon aquacultural production and welfare. Fish, Physiology and Biochemistry, 38(1), 61-83. https://doi.org/10.1007/s10695-011-9557-1

Okafor A. I., \& Achilefu, L. N. (2017). Haematological responses to stress of transportation and acclimation on the african catfish, Heterobranchus bidorsalis (Geoffrey, Saint Hilare). Journal of Experimental Research, $5(1), 18-23$.

Oliveira, R. F., Mcgregor, P. K., \& Latruffe, C. (1998). Know thine enemy: fighting fish gather information from observing conspecific interactions. Philosophical Transactions of the Royal Society B: Biological Sciences, 265, 1045-1049. https://doi.org/10.1098/rspb.1998.0397

Oliveira, S. R. S. de, Pinheiro-Sousa, D. B., Almeida, Z. da S. de, Castro, J. da S., \& Carvalho-Neta, R. N. F. (2016). Lesões histopatológicas como biomarcadores de contaminação aquática em Oreochromis niloticus (Osteichthyes, Cichlidae) de uma área protegida no Maranhão. Revista Brasileira de Engenharia de Pesca, 9(1), 12-26. https://doi.org/10.18817/repesca.v9i1.1105

Orji, R. C. A. (2005). The effect of transportation stress on haematocrit level of Orechromis niloticus. Animal Research International, 2(1), 224-226. https://doi.org/10.4314/ari.v2i1.40842

Portz, D. E., Woodley, C. M., \& Cech Junior, J. J. (2006). Stress-associated impacts of short-term holding on fishes. Fish Biology and Fisheries, 16(2), 125-70. https://doi.org/10.1007/s11160-006-9012-z

Ranzani-Paiva, M. T. J., \& Silva-Souza, A. T. (2004). Hematologia de Peixes Brasileiros. In M. T. J. Ranzani-Paiva, R. M. Takemoto, \& M. A. P. Lizama (Eds.), Sanidade de Organismos Aquáticos (pp. 104-107). São Paulo: Editora Varela.

Rodrigues, G. M., Nasncimento, F. G. de O., Bizare, A., Oliveira, W. J., Guimarães, E. C., \& Mundim, M. A. V. (2018). Serum biochemical profile of nile tilapias (Oreochromis niloticus) bred in net cages during summer and winter. Acta Scientiae Veterinariae, 46(1), 15-29. https://doi.org/10.22456/1679-9216.81814

Schwartzkopf-Genswein, K. S., Faucitano, L. S., Dadgar, P., Shand, L. A., \& González, T. G. (2012). Road transport of cattle, swine and poultry in North America and its impact on animal welfare, carcass and meat quality: A review. Meat Science, 92, 227-243. https://doi.org/10.1016/j.meatsci.2012.04.010

Silva, R. D. D., Rocha, L. O., Fortes, B. D. A., Vieira, D., \& Fioravanti, M. C. S. (2012). Parâmetros hematológicos e bioquímicos da tilápia-do Nilo (Oreochromis niloticus) sob estresse por exposição ao ar. Pesquisa Veterinária Brasileira, 32(1), 99-107. https://doi.org/10.1590/S0100-736X2012001300017

Smith, G. C., Grandin, T., Friend, T. H., Don Lay, J. R. E., \& Swanson, J. C. (2004). Effect of transport on meat quality and animal welfare of cattle, pigs, sheep, horses, deer and poultry. Kansas State University, USA. Retrieved from http://www.grandin.com/behaviour/effect.of.transport.html

Tavares-Dias, M., \& Moraes, F. R. (2004). Hematologia de peixes teleósteos (p. 144). Ribeirão Preto: Villimpress.

Tavares-Dias, M., Bozzo, F. R., Sandrin, E. F. S., Campos-Filho, E. de, \& Moraes, F. R. de. (2004). Células sangüíneas, eletrólitos séricos, relação hepato e esplenossomática de carpa-comum, Cyprinus carpio (Cyprinidae) na primeira maturação gonadal. Acta Scientiarum. Biological Sciences, 26(1), 73-80. https://doi.org/10.4025/actascibiolsci.v26i1.1661

Teixeira, E. G. (2007). Adaptação de metodologias de manejo reprodutivo como subsídios para a implantação de um programa de melhoramento genético da tilápia do Nilo (Oreochromis niloticus) variedade Chitralada no Centro de Pesquisa em Aqüicultura (p. 111, Dissertação (Mestrado em Engenharia de Pesca), Departamento de Engenharia de Pesca, Universidade Federal do Ceará, Fortaleza, Brazil). 
Texeira Filho, A. R. (1991). Piscicultura ao Alcance de Todos (p. 212). São Paulo, Nobel.

Tran-Duy, A., Schrama, A. J. W., Vam Dam, A. A., \& Verret, J. A. J. (2008). Effects of oxygen concentration and body weight on maximum feed intake, growth and hematological parameters of Nile tilapia, Oreochromis niloticus. Aquaculture, 275, 152-162. https://doi.org/10.1016/j.aquaculture.2007.12.024

Turnbull, J. F., \& Kadri, S. (2007). Safeguarding the many guises of farmed fish welfare. Diseases of Aquatic Organisms, 75(2), 173-182. https://doi.org/10.3354/dao075173

Val, A. L. (1996). Surviving low oxygen levels: Lessons from fishes of the Amazon. In A. L. Val, V. M. F. Almeida-Val, \& D. J. Randall (Eds.), Physiology and Biochemistry of the fishes of the Amazon (pp. 50-73). Manaus, Ed. Manaus.

Vernerey, F. J., \& Barthelat, F. (2010). On the mechanics of fishscale structures. International Journal of Solids and Structures, 47(17), 2268-2275. https://doi.org/10.1016/j.ijsolstr.2010.04.018

Vidal, V. O., Albinati, R. C. B., Albinati, A. C. L., Lira, A. D. Almeida, T. R., \& Santos, G. B. (2008). Eugenol como anestésico para a tilápia-do-Nilo. Pesquisa Agropecuária Brasileira, 43(8), 1069-1074. https://doi.org/10.1590/S0100-204X2008000800017

Volpato, G. L., \& Fernandes, M. O. (1994). Social Control of Growth in Fish. Brazilian Journal of Medical and Biological Research, 27(4), 797-810.

Wintrobe, M. M. (1934). Variations in the size and he-moglobin content of erythrocytes in the blood of various vertebrates. Folia Haematologica, 51(1), 32-49.

Wolff, L. L., \& Donatti, L. (2016). Estudo do comportamento do peixe de água doce Pphalloceros harpagos (Cyprinodontiformes: Poeciliidae) submetido à alteração artificial do pH. Luminária, 18(1), 10-21. Retrieved from http://periodicos.unespar.edu.br/index.php/luminaria/article/view/1026/587

\section{Copyrights}

Copyright for this article is retained by the author(s), with first publication rights granted to the journal.

This is an open-access article distributed under the terms and conditions of the Creative Commons Attribution license (http://creativecommons.org/licenses/by/4.0/). 